\title{
Dominant stakeholders, activity and accountability discharge in the CSO Sector
}

\author{
Carolyn J. Cordery ${ }^{1}$ and Dalice Sim $^{2}$ \\ 1. Victoria University of Wellington \\ 2. University of Otago
}

Corresponding Author: Carolyn Cordery, School of Accounting and Commercial Law, Victoria University of Wellington, P O Box 600, Wellington, New Zealand. P: 644 463-5761; F: 644463 5076; E: Carolyn.Cordery@vuw.ac.nz

Dalice Sim, School of Mathematics, Statistics and Operations Research, Victoria University of Wellington, P O Box 600, Wellington, New Zealand. E: Dalice.Sim@vuw.ac.nz

\begin{abstract}
:
Civil Society Organisations (CSOs) comprise a diverse range of associations, including NGOs, community groups, political parties and social networks. Nevertheless, despite heterogeneity, regulators, funders and donors often treat CSOs as homogeneous when demanding accountability. This paper highlights differences in to whom CSOs across different categories (or types) perceive themselves to be accountable, what for, and the different practices they undertake to discharge accountability. It calls for stakeholders to acknowledge diversity in accountability across different CSO types. This survey-based research finds CSOs weight upwards and downwards stakeholders equally, and undertake voluminous reporting. They would benefit from negotiating multiple-use mechanisms, especially with dominant stakeholders. In combining stakeholder and accountability theory, the research highlights specific CSO types needing further study.
\end{abstract}

Keywords: CSO accountability; Advocacy CSOs; Infrastructure CSOs; Foundation accountability, Social Service CSOs, Charities, Membership CSOs 


\section{Dominant stakeholders, activity and accountability discharge in the CSO Sector}

\section{INTRODUCTION}

Unprecedented growth in civil society organisations (CSOs) evidences a global associational revolution (Salamon et al, 2012). ${ }^{\mathrm{i}}$ Extensive cross-country research finds that, on average, voluntary and paid CSO staff represent $7.4 \%$ of countries' total workforces and CSOs contribute $4.5 \%$ to GDP (Salamon et al, 2012). While most literature analyses NGOs (nongovernmental organisations), an iceberg-like body of CSOs 'beneath' NGOs includes community groups, political parties and social networks (Edwards, 2000). CSOs are formal, private organisations, separate from government, self-governing, non-profit-distributing, and have a meaningful degree of voluntary participation (Salamon \& Anheier, 1992b). Some CSOs are very large, operating internationally in aid or social services (SustainAbility et al, 2003), but the great majority are small and locally-based.

CSOs raise funds from members, private donors, businesses, service recipients and governments. Nevertheless, information asymmetry means that CSOs may act opportunistically with governments' and donors' funds (Cordery \& Baskerville, 2011; Desai \& Yetman, 2005). Further, CSOs may digress from their goals and mission (Koppell, 2005; Lehman, 2007; Loft et al, 2006). Accordingly, Hyndman and McDonnell (2009, p. 5) note "growing public expectations for accountability and transparency" brings increasing regulation of CSOs, particularly charities. CSOs' stakeholders hold divergent expectations of how CSOs should execute their missions (Valentinov, 2011), but its activities are important. For example, an advocacy CSO may be held accountable for the impact of its political activities (Unerman \& O'Dwyer, 2006b), or a development CSO/NGO for its engagement with local communities (Dixon et al, 2006; Goddard \& Assad, 2006). In addition, different mechanisms may be expected (Ebrahim, 2003b); with funders demanding formal reports, but recently, more democratic reporting (Hyndman \& McDonnell, 2009).

Individual case studies of accountability are increasingly common and evidence diversity (for example, Awio et al, 2011; Brown \& Moore, 2001; Cordery et al, 2011; O’Dwyer \& Unerman, 2008). Nevertheless, theoretical and pan-sector research (for example, Najam, 1996; Roberts, 1991; Valentinov, 2011) seldom suggests that differently-funded CSOs might perceive accountability differently (except for Brown \& Moore, 2001; Ebrahim, 2003b). 
Further, CSO regulators operate as if CSOs' dominant stakeholders and their accountability expectations are similar (Cordery et al, 2015). Alternatively, this pan-sector research describes similarities and differences, enquiring how diversity in dominant stakeholders and activity affect accountability discharge across the CSO sector. We argue that accountability (i.e. to whom, for what and how) is not homogeneous, but dependent on CSOs' dominant stakeholders and their activity and that, when CSOs are categorised into sub-sectors or types, each cluster exhibits unique accountability profiles.

In defining and describing CSOs' accountability similarities and differences, this research responds to Hyndman and McDonnell's (2009, p. 28) call for “quantitative analysis looking at forms of accountability" and its discharge. Further, it extends Brown and Moore's (2001) structural differences argument of from three to six CSO types, with empirical backing. Thus, we contribute to the literature in three ways. We highlight variations between different CSO types, inviting CSOs' stakeholders to adapt their accountability expectations. Secondly, in focusing on CSOs' perceptions of accountability, we add to Cordery et al's (2015) six-type CSO categorisation. Thirdly, while that categorisation is developed from theories about why CSOs form and how they are funded, this research responds to Gray et al's (2006) call for a principles-based approach to accountability. Without a suitable theoretical and empirical schema, our understanding of CSOs is limited (Vakil, 1997); accountability theory development is also impeded. Although others infer differences, this research overtly assesses conceptual nuances of accountability across different CSO types at a meso-level.

The paper first explains CSO categorisation, then accountability theory. The context and research methods are described and findings presented, before the discussion, limitations and future research opportunities.

\section{CATEGORISING CSOS}

CSO definitions include the de facto approach (CSOs are nongovernment, nonprofit) and the de jure approach (structurally legally incorporated). However, CSOs' activities are important (Teegen et al, 2004; Unerman \& O’Dwyer, 2006a). Therefore, Salamon and Anheier's (1992a, 1992b) structural/operational categorisation combines de facto and de jure definitions, further categorising CSOs by 12 different activities ${ }^{\mathrm{ii}}$. Other researchers dichotomise CSO activities, or focus on one CSO type. For example, Unerman \& O'Dwyer (2006b) bifurcate CSOs into welfare providers or advocacy NGOs; Dawson (1998) divides 
international NGOs into 'Southern' NGOs (serving developing countries) and 'Northern' NGOs (advocating in developed nations).

Alternatively, organisational theorists categorise CSO management/control. For example, Hansmann (1986) dichotomises CSOs as either mutuals (member-controlled), or independently managed. Further, Hansmann (1986) states CSOs are either 'donative', (receive donations), or 'commercial', charging for goods and services. Connolly et al (2013) bifurcate charities into fundraisers and grantors.

Focusing on funding and control makes stakeholders fundamental to categorising CSOs. Stakeholders are "any group or individual who can affect or is affected by the achievement of the organisation's objectives" (Freeman, 1994, p. 46). They include powerful regulators and key resource providers who may marginalise less-powerful stakeholders such as beneficiaries, local communities, media, employees and suppliers (Cordery \& Baskerville, 2011; Irvin, 2005). Mitchell et al (1997) maintain that salient stakeholders possess power, legitimacy, and urgency. Powerful stakeholders demand CSO compliance, while legitimate stakeholders hold legal or moral claims (Cordery \& Baskerville, 2011; Mitchell et al, 1997). Mitchell et al (1997) deem stakeholders with both power and legitimacy to be dominant. ${ }^{\text {iii }}$

Thus, a CSO categorisation should differentiate CSOs' funding and activities, to recognise funders and regulators' power and legitimacy (Mitchell et al, 1997), CSOs' management and control (Hansmann, 1986, Connolly et al, 2013) and activities (Salamon \& Anheier, 1992a, 1992b; Teegen et al, 2004; Unerman \& O’Dwyer, 2006b). We use Cordery et al's (2015) charity categorisation based on funding and activities, extending it to CSOs more broadly. Using classical statistical clustering techniques, Cordery et al (2015) identify five charity 'types' from financial data. Revenue sources sharply differentiate CSOs, highlighting resource providers as key CSO stakeholders. The different types are: Classic Charities, Membership, Infrastructure, Trusts/Grantors, and Service Providers. We include Advocacy organisations as a sixth type as they are prominent in the literature, but cannot register as charities, thus Cordery et al (2015) omitted them.

- Advocacy CSOs: advocate for better government or corporate policies for disadvantaged groups/causes (for example, Amnesty International, Greenpeace). Ebrahim (2003b) calls them 'networked' organisations, Brown and Moore (2001) policy and institutional influence CSOs. They bring change by powerfully 'speaking with' or 'speaking for' the disadvantaged (Teegen et al, 2004; Unerman \& O'Dwyer, 
2006b). Advocacy CSOs are relatively unregulated. Membership fees and public donations comprise their main revenues which are significantly larger, on average, than other CSO types. Although Advocacy CSOs hold attributes of Membership CSOs and Classic Charities, they are distinguished by their activities which give voice to those 'from below', and the low salience of regulators as stakeholders.

- Classic Charities: are resourced mainly by public donations $(\approx 85 \%)$ (Cordery et al, 2015). They support beneficiaries (Gray et al, 2006); and are increasingly regulated (Cordery et al, 2015). Classic Charities include religious organisations, environmental charities, and those assisting youth, the aged, and animals (Lehman, 2007; Statistics New Zealand, 2007) (for example, SPCA, Salvation Army). These CSOs receive donations of money, goods, volunteer time, and from staff who are paid less than market value (Brown \& Moore, 2001).

- Infrastructure CSOs: provide facilities, structures and systems to support and coordinate front-line CSOs to empower effective mission delivery (Cupitt \& Mihailidou, 2009) (for example, by owning an office block, hospital or community hall, and renting it to CSOs cheaply). They also build alliances with, for example, local government or schools to support the CSO sector (Brown \& Kalegaonkar, 2002). In providing physical spaces, Infrastructure CSOs enable a service provider to focus on specialist services; they also potentially enhance democracy through providing public meeting spaces. Rental comprises their main income source $(\approx$ 73\%), they borrow more, and own significant Property, Plant and Equipment (Cordery et al, 2015). These CSOs differ from for-profit infrastructure providers by their social values and mission.

- Membership CSOs: exhibit different revenue and expenditure patterns to other CSOs, with membership fees providing most funding $(\approx 42 \%)$. On average, they have the highest levels of sponsorship $(\approx 5 \%)$ and more revenue sources than other CSOs (Cordery et al, 2015). Membership CSOs are "largely oriented toward serving the interests of their members and ... [are] diverse" (Ebrahim, 2003b, p. 204) (for example, amateur sports clubs, local orchestras).

- Trusts/Grantors (Philanthropist CSOs): are essential to the CSO sectors' on-going sustainability. They include self-funded, company sponsored or community funded trusts/foundations whose major revenue is investment returns $(\approx 92 \%)$; from which they make philanthropic grants (Cordery et al, 2015; Coyte et al, 2013; Leat, 2004). 
Nevertheless, given they are largely private institutions receiving tax concessions, their accountability is questioned (Irvin, 2005; Jung \& Harrow, 2014; Tomei, 2013).

- Service Providers: mainly receive revenues from delivering goods and services $(\approx$ 72\%) (Cordery et al, 2015) in the health, legal, museum and theatre sectors, and international aid (Brown \& Moore, 2001; DiMaggio \& Anheier, 1990). Increasingly, governments are their main funders (Bennett \& Savani, 2011). They differ from forprofit providers due to their nonprofit motive, and differ from Membership CSOs as members only weakly, or do not, direct operations (Ebrahim, 2003b; Weisbrod, 1988).

As with any CSO segmentation, this categorisation has limitations. The lines between forprofit entities and CSOs is blurred (DiMaggio \& Anheier, 1990; Hwang \& Powell, 2009), and some CSOs straddle categories. However, DiMaggio and Anheier (1990) argue for 'ecological' research that views differences between forms. This ecological research utilises the combined stakeholder/activity schema devised and tested by Cordery et al (2015), being broader than dichotomisations by Unerman and O'Dwyer (2006a), Dawson (1998) and Hansmann (1986), and more parsimonious than Salamon and Anheier (1992a, 1992b). We test the Cordery et al (2015) categorisation against CSOs' accountability perceptions.

Differences in accountability would support the categorisation, whereas high similarities would suggest otherwise.

\section{CSO ACCOUNTABILITY}

Laughlin (1990) notes that case studies were previously ignored, with accountability research being largely theoretical. He began a research stream of case studies into CSO resourcing and accountability. This section interrogates CSO accountability through case study literature which highlight the necessity to identify:

- 'to whom' CSOs owe accountability (in particular, whether stakeholders are upwards or downwards);

- 'for what' CSOs are accountable (in particular, for functional or strategic outcomes); and

- 'how' CSOs might discharge accountability (in particular, whether mechanisms are retrospective or prospective). 
We contend these aspects of CSOs' accountability differ, depending on CSOs' activities and dominant stakeholders. Utilising the CSO categorisation, we ask "how does this diversity affect accountability discharge in the CSO sector"? This literature review sorts case studies into CSO types defined by the studies' authors. However our analysis in the results section defines CSOs based on revenue and activity (as in Cordery et al, 2015).

\section{'To whom' accountability is owed}

CSOs lack for-profit entities' single focus on profit and shareholders as primary stakeholders. Instead, multiple groups impose competing demands and potentially conflicting incentives and sanctions (Dixon et al, 2006; Ebrahim, 2003b; Edwards \& Hulme, 1996; Valentinov, 2011). For example, social service providers face tensions "between expanding accountability to the fullest level of disclosure and the widest range of stakeholders and between limiting disclosure format and stakeholder range to preserve maximum sponsor/donor financial support" (Parker, 2003, p. 368). Sponsors and donors are dominant and salient stakeholders, holding power and legitimacy (Mitchell et al, 1997). Thus, CSOs priroritise their accountability demands.

Roberts (1991) bifurcates accountability into hierarchical (upwards) and socialising (downwards or lateral accountability). ${ }^{\text {iv }}$ Irvin (2005) explains that CSOs more readily account upwards to government funders and trustees, than downwards to beneficiaries and other CSOs. Although beneficiaries seek accountability for service delivery quality (Connolly et al, 2013), upwards accountability can impair service delivery or reduce beneficiaries' benefits (Agyemang et al, 2009; Dixon et al, 2006; Goddard \& Assad, 2006). Resource dependency and CSOs' need for financial sustainability drive an upwards stakeholder bias. Therefore, despite possessing legitimacy, downwards stakeholders without power or urgency may be ignored by CSOs' accountability processes (Connolly et al, 2013; Cordery et al, 2011; Cordery \& Baskerville, 2011; Dixon et al, 2006; Mitchell et al, 1997; Mourey et al, 2013; Najam, 1996).

Hence, while Brown and Moore (2001) argue that Advocacy CSOs should be accountable for their impact on the downwards stakeholders for whom they advocate, studies find they prioritise upwards accountability to funders and regulators instead (Ebrahim, 2003b; Knutsen \& Brower, 2010), with O'Dwyer and Unerman (2008) reporting that managers in one Advocacy CSO are unsure of how to engage with stakeholders other than funders. 
In CSOs funded largely by donors (Classic Charities), Jayasinghe and Wickramasinghe (2011) find a lack of participatory mechanisms for downwards stakeholders, and contend that donors (upwards stakeholders) are poorly informed about local operations. Despite powerful funders increasingly calling for beneficiary perspectives to accountability, O’Dwyer and Unerman (2007) and O'Dwyer and Boomsma (2015) note insufficient institutionalisation of downwards engagement. Yet, beneficiaries may not wish to engage, are hard to identify and require specialised reporting (Connolly et al, 2013).

Similarly, Service Provider CSOs rank donors and clients claims above employees, partners, and co-producers (Brown and Moore, 2001). However, Cribb (2006) argues that Service Provider CSOs' staff feel more accountable to clients and staff than government funders. Indeed, in another Service Provider CSO, Awio et al (2011, p. 85) find "strong community involvement in public services provision and management" with downwards accountability being appropriately discharged. Therefore, Tenbensel et al (2007) reason that government funders should encourage CSOs to develop downward accountabilities, by demanding additional ancillary services to aid beneficiaries (Bennett \& Savani, 2011), close staff liaison (Christensen \& Ebrahim, 2006), or requiring greater user involvement (Hyndman \& McDonnell, 2009).

Little academic literature is available on infrastructure providers, however practitioner literature suggests that Infrastructure CSOs attempt to discharge accountability both upwards to funders and downwards to their users (Cupitt \& Mihailidou, 2009; Macmillan, 2008).

Membership CSOs should excel at downwards accountability, as they are "largely oriented towards serving the interests of their members ... [and] are primarily run by and for their members" (Ebrahim, 2003b, p. 204). This includes prioritising participation, encouraging members to exercise democratic accountability, and ensuring financial sustainability (Anheier $\&$ Themudo, 2002; Loft et al, 2006; Ospina et al, 2002). Nevertheless, as Membership CSOs receive funds from more diverse stakeholders and activities than other CSO types, they often experience "multiple accountabilities disorder" (Koppell, 2005, p. 94), in prioritising salient stakeholders.

Similar concerns, that downwards stakeholders are ignored, apply when Philanthropists fund projects without considering community's interests (Coyte et al, 2013; Leat, 2004). Many Philanthropist CSOs fail to draw on community knowledge when grant-making (Botetzagias \& Koutiva, 2014; Delfin \& Tang, 2006; Tomei, 2013). Nevertheless, while poor 
Philanthropist accountability is highlighted, there is a paucity of research into 'to whom' these CSOs believe they are accountable.

Table 1 lists stakeholders identified in the literature, classified as upwards or downwards, although some stakeholders may fit both classifications. Investigating these stakeholders, we ask for each CSO type:

(i) What is the total number of different stakeholder groups that CSOs report to or engage with?; and

(ii) What is the emphasis on upwards or downwards stakeholders?

Table 1: Upwards and downwards stakeholders 'to whom' accountability is owed from Roberts (1991) and Edwards and Hulme (1996)

\begin{tabular}{|l|l|l|}
\hline Type & Stakeholder & Selected References \\
\hline \multirow{4}{*}{ Upwards } & Donors & $\begin{array}{l}\text { Hyndman \& McDonnell (2009); Najam } \\
(1996)\end{array}$ \\
\cline { 2 - 3 } & Funders, government contracts & $\begin{array}{l}\text { Hyndman \& McDonnell (2009); Parker } \\
(2003) ; \text { Irvine et al (2009) }\end{array}$ \\
\cline { 2 - 3 } & Government (other than for contracts) & $\begin{array}{l}\text { Hyndman \& McDonnell (2009); Najam } \\
(1996) ; \text { O’Dwyer and Boomsma (2015) }\end{array}$ \\
\cline { 2 - 3 } & Grant makers & $\begin{array}{l}\text { Hyndman \& McDonnell (2009); Najam } \\
(1996)\end{array}$ \\
\cline { 2 - 3 } & Lenders & Cupitt \& Mihailidou (2009) \\
\cline { 2 - 3 } wards & Our Board/management committee & Parker (2003); Najam (1996) \\
\cline { 2 - 3 } & Members & Parker (2003); Ebrahim (2003b b) \\
\cline { 2 - 3 } & Service Recipients/beneficiaries & $\begin{array}{l}\text { Hyndman \& McDonnell (2009); Najam } \\
(1996) ; \text { O'Dwyer and Unerman (2007) }\end{array}$ \\
\cline { 2 - 3 } & Our Staff & Brown \& Moore (2001); Cribb (2006) \\
\cline { 2 - 3 } & Those for whom we advocate & Cupitt \& Mihailidou (2009) \\
\cline { 2 - 3 } & CSOs that use our infrastructure & Brown \& Moore (2001) \\
\cline { 2 - 3 } & International Political \& Military actors & \\
\hline
\end{tabular}

\section{'For what' accountability is owed}

A second major aspect of accountability is 'for what'? Functional accountability requires accountability for CSOs' resource use and short-term impacts (Ebrahim, 2003b; Najam, 1996). ${ }^{\vee}$ Strategic accountability for CSOs' long-term outcomes and mission achievement is also necessary (Ebrahim, 2003b; Edwards \& Hulme, 1996; Najam, 1996). Najam (1996) hypothesises that CSOs discharge high levels of functional and medium strategic accountability to donors, low functional and strategic internally, and are unlikely to discharge functional or strategic accountability to clients. Agyemang et al (2009) agrees that dominant 
(powerful and legitimate) stakeholders demand functional reporting, restricting CSOs' strategic accountability. Nevertheless, CSOs must balance functional and strategic accountability to successfully navigate stakeholders' complex and dynamic demands (Hyndman \& McDonnell, 2009; Parker, 2003).

Strategic planning is necessary for CSOs seeking long-term change (Brown \& Moore, 2001), yet Lehman (2007) contends that Advocacy CSOs lack appropriate strategic accountability. Lehman (2007) argues they should advocate against systemic issues of capitalism, commodification and globalisation, but instead Advocacy CSOs garner legitimacy with powerful governments and funders, reducing their effectiveness as change agents.

Some Classic Charities strategically bargain for change to achieve their mission, as seen in Goddard and Assad's (2006) Tanzanian charities and O’Dwyer and Boomsma's (2015) study of Oxfam Novib. These charities negotiate change with their powerful and legitimate (dominant) upwards stakeholders.

Macmillan (2008) expects Infrastructure CSOs to develop collaborative long-term 'investment proposals', strategically planning to enhance the CSO sector's capacity. ${ }^{\text {vi }} \mathrm{He}$ believes they must build infrastructure such as low-cost (or free) rental accommodation or facilities. Nevertheless, Macmillan (2008) finds Infrastructure CSOs lack strategic accountability, allocate resources unfairly, fail to plan long-term, and limit the CSO sector's sustainability.

Membership CSOs' accountability is more functionally, than strategically focused. They prioritise efficiency over responsiveness (Koppell, 2005), technical competency over representation (Loft et al, 2006), and gather ex-post and short-term ex-ante information (Laughlin, 1990).

Strategic accountability is vital for Philanthropists: for their long-term impact on fundees (see Mckinney \& Kahn, 2004) and for their ethical investment of trust funds (Kreander, Beattie, \& McPhail, 2009). Strategic investments should optimise monetary and non-monetary societal benefits.

Service Providers' focus on functional over strategic accountability is driven by short-term funding and increasing competition from for-profit providers (Ebrahim, 2003a). For example, Cribb (2006) found Service Provider CSOs stated they felt functionally accountable for service provision. 
Table 2 lists possible reasons for accountability identified in the literature, classified as functional or strategic, although some may fit both classifications. Accountability reasons either respond to ongoing urgent stakeholder demands, or CSOs' values and mission. Investigating these reasons, we ask for each CSO type:

(i) What is the total number of reasons for CSOs to report or engage with stakeholders?; and

(ii) What is the emphasis on functional or strategic reasons?

Table 2: Functional and strategic accountability 'for what' Accountability is owed from Ebrahim (2003b) and Najam (1996)

\begin{tabular}{|c|c|c|}
\hline Type & Statement of why accountable & Selected References \\
\hline \multirow[t]{8}{*}{$\begin{array}{l}\text { Func- } \\
\text { tional }\end{array}$} & $\begin{array}{l}\text { We can continue to obtain funds and donations for } \\
\text { our operations }\end{array}$ & $\begin{array}{l}\text { Irvine et al (2009); O'Dwyer } \\
\text { and Boomsma (2015) }\end{array}$ \\
\hline & $\begin{array}{l}\text { We can continue to deliver quality programmes and } \\
\text { services (to members/ beneficiaries) }\end{array}$ & $\begin{array}{l}\text { Parker (2003); O’Dwyer and } \\
\text { Boomsma (2015) }\end{array}$ \\
\hline & Our community is content with our current activities & Osborne et al (1995) \\
\hline & We satisfy lenders/ investors & Cupitt \& Mihailidou (2009) \\
\hline & We maintain our infrastructure for others to use & Irvine et al (2009) \\
\hline & $\begin{array}{l}\text { We can make good decisions about making grants to } \\
\text { others }\end{array}$ & $\begin{array}{l}\text { Coyte, et al (2013); Irvine et } \\
\text { al (2009) }\end{array}$ \\
\hline & We can maximise the return on our investments & Osborne et al (1995) \\
\hline & We are internally effective and efficient & $\begin{array}{l}\text { Hyndman \& McDonnell } \\
\text { (2009) }\end{array}$ \\
\hline \multirow[t]{8}{*}{$\begin{array}{l}\text { Stra- } \\
\text { tegic }\end{array}$} & $\begin{array}{l}\text { We show how we are delivering on our organisation's } \\
\text { mission or long term strategic plan }\end{array}$ & Parker (2003) \\
\hline & We are responsive to the community's ongoing needs & Irvine et al (2009) \\
\hline & $\begin{array}{l}\text { We can make representative decisions in our } \\
\text { organisation }\end{array}$ & $\begin{array}{l}\text { Brown and Moore (2001); } \\
\text { Hyndman \& McDonnell } \\
\text { (2009) }\end{array}$ \\
\hline & $\begin{array}{l}\text { We can collaborate with other community and } \\
\text { voluntary sector organisations }\end{array}$ & $\begin{array}{l}\text { Brown and Moore (2001); } \\
\text { Irvine et al (2009); O'Dwyer } \\
\text { and Boomsma (2015) }\end{array}$ \\
\hline & $\begin{array}{l}\text { We can show how we support other community and } \\
\text { voluntary sector organisations }\end{array}$ & $\begin{array}{l}\text { Brown and Kalegaonkar } \\
(2002)\end{array}$ \\
\hline & We are honest about our long term impact on others & Brown and Moore (2001) \\
\hline & $\begin{array}{l}\text { We can plan for the future of the community and } \\
\text { voluntary sector and our role in supporting it }\end{array}$ & Osborne et al (1995) \\
\hline & We can show that we invest ethically & Kreander et al (2009) \\
\hline
\end{tabular}

\section{'How' accountability is discharged}

Mechanisms for discharging accountability vary (Ebrahim, 2003b; Goddard \& Assad, 2006), being retrospective (ex-post), or prospective (ex-ante). Prospective mechanisms include 
Advocacy CSOs' lobbying, litigating, protesting, fact-finding, and coordinating change (Ebrahim, 2003b). They retrospectively report on these activities' impact (O'Dwyer \& Unerman, 2008). However, work pressures may diminish prospective accountability (Knutsen \& Brower, 2010). O’Dwyer and Unerman (2008) find an Advocacy CSO's new prospective mechanisms swamped by upwards retrospective accountability demands.

Retrospective mechanisms in Classic Charities are narrow and quantitative, as donors impose annual budget cycles, formal quality systems and accreditation (O’Dwyer \& Boomsma, 2015). Connolly et al (2013) find that donors and beneficiaries believe external retrospective reports important, but previously lacked relevance. Although reporting is increasingly relevant, the information ranked as 'most important' (how resources had been used in meeting beneficiaries' needs) is inadequate (Connolly et al, 2013). Further, Classic Charities' regulatory filings evidence low prospective accountability (for example, Cordery \& Patel, 2011), despte Dawson (1998) listing numerous prospective mechanisms for Classic Charities, highlighting participatory mechanisms.

In Membership CSOs, important retrospective accountability mechanisms include oral and other informal reporting such as Annual General Meetings (AGMs), newsletters, and informal statements from the chair/president about member activities (Awio et al, 2011; Ospina et al, 2002). Retrospective mechanisms also include dealing with dissatisfied members' complaints (Knutsen \& Brower, 2010). Membership CSOs' prospective consultative mechanisms, such as elections and open meetings (Koppell, 2005), enable strategy development (Brown \& Moore, 2001).

Macmillan (2008) calls for Infrastructure CSOs to provide more prospective reporting. They should demonstrate the difference they make, and prospectively report on their plans (Cupitt \& Mihailidou, 2009).

Similarly, Leat (2004) notes that, when required to be accountable, Philanthropists provide retrospective information only. Nevertheless, given their impact on funded CSOs, Mckinney \& Kahn (2004) call for reform.

Cutt et al (1996) find Service Providers report differing levels of prospective and retrospective information to different stakeholders. Retrospective mechanisms focus on funding and short-term impact (functional accountability), but potentially increasing prospective mechanisms will discharge strategic accountability (Cutt et al, 1996). 
Table 3 lists possible accountability mechanisms, classified as retrospective or prospective although some may mix retrospective and prospective. ${ }^{\text {vii }}$

Table 3: Retrospective and Prospective Accountability Mechanisms

\begin{tabular}{|c|c|c|}
\hline Type & Mechanism & Selected References \\
\hline \multirow[t]{6}{*}{$\begin{array}{l}\text { Retro- } \\
\text { spective }\end{array}$} & $\begin{array}{l}\text { Reported to funder/s (financial and other } \\
\text { information) }\end{array}$ & $\begin{array}{l}\text { Hyndman \& McDonnell (2009); } \\
\text { O'Dwyer and Boomsma (2015) }\end{array}$ \\
\hline & Published an Annual Report & $\begin{array}{l}\text { Edwards and Hulme (1996); Cutt } \\
\text { et al (1996) }\end{array}$ \\
\hline & Held an AGM of members & Laughlin (1990); Cordery (2005) \\
\hline & $\begin{array}{l}\text { Had our financial data independently audited } \\
\text { or reviewed }\end{array}$ & $\begin{array}{l}\text { Christensen and Ebrahim (2006); } \\
\text { Goddard and Assad (2006) }\end{array}$ \\
\hline & Published a budget (1-2 years) & $\begin{array}{l}\text { Laughlin (1990); Parker (2003); } \\
\text { Kluvers (2001) }\end{array}$ \\
\hline & $\begin{array}{l}\text { Gained accreditation for our services from an } \\
\text { independent organisation }\end{array}$ & $\begin{array}{l}\text { Brown and Moore (2001); } \\
\text { O'Dwyer and Boomsma (2015) }\end{array}$ \\
\hline \multirow[t]{6}{*}{$\begin{array}{l}\text { Prospec- } \\
\text { tive }\end{array}$} & $\begin{array}{l}\text { Consulted with members on structural or } \\
\text { constitutional changes to our organisation }\end{array}$ & Brown and Moore (2001) \\
\hline & $\begin{array}{l}\text { Consulted with service users or beneficiaries } \\
\text { (other than members) }\end{array}$ & $\begin{array}{l}\text { Hyndman \& McDonnell (2009); } \\
\text { Dawson (1998) }\end{array}$ \\
\hline & $\begin{array}{l}\text { Held elections for new representatives on our } \\
\text { Board/ management committee }\end{array}$ & $\begin{array}{l}\text { Hyndman \& McDonnell (2009); } \\
\text { Koppell (2005) }\end{array}$ \\
\hline & Published a strategic plan (3-5 years out) & Hyndman \& McDonnell (2009) \\
\hline & Sent out a press release about our organisation & Valentinov (2011) \\
\hline & $\begin{array}{l}\text { Held Board/management committee meetings } \\
\text { which are open to the public }\end{array}$ & $\begin{array}{l}\text { Brown and Moore (2001); } \\
\text { Koppell (2005) }\end{array}$ \\
\hline
\end{tabular}

Recognising the importance of retrospective, but calls for prospective mechanisms, we ask for each CSO type:

(i) What is the total number of different mechanisms CSOs use to report to or engage with stakeholders?; and

(ii) What is the emphasis on retrospective or prospective mechanisms?

Table 4 summarises this literature review. 
Table 4: CSO Accountability Categorisations (extending Cordery et al, 2015)

\begin{tabular}{|c|c|c|c|}
\hline Type of CSO & $\begin{array}{c}\text { To whom (upwards/ } \\
\text { downwards) }\end{array}$ & $\begin{array}{l}\text { For what } \\
\text { (functional/ } \\
\text { strategic) }\end{array}$ & $\begin{array}{c}\text { How } \\
\text { (retrospective/ } \\
\text { prospective) }\end{array}$ \\
\hline $\begin{array}{l}\text { Advocacy } \\
\text { CSOs }\end{array}$ & \multirow{2}{*}{$\begin{array}{l}\text { Balanced, more } \\
\text { downwards needed } \\
\text { to offset upwards } \\
\text { dominance } \\
\text { (Agyemang et al, } \\
\text { 2009; Jayasinghe \& } \\
\text { Wickramasinghe, } \\
\text { 2011; Knutsen \& } \\
\text { Brower, 2010; } \\
\text { O’Dwyer \& } \\
\text { Boomsma, 2015) }\end{array}$} & $\begin{array}{l}\text { Strategic prioritised } \\
\text { over functional } \\
\text { (Brown \& Moore, } \\
\text { 2001) }\end{array}$ & $\begin{array}{l}\text { Balanced, requiring more } \\
\text { prospective mechanisms } \\
\text { (Ebrahim, 2003b; } \\
\text { Knutsen \& Brower, } \\
\text { 2010) }\end{array}$ \\
\hline $\begin{array}{l}\text { Classic } \\
\text { Charities }\end{array}$ & & $\begin{array}{l}\text { Balanced between } \\
\text { strategic and } \\
\text { functional (O’Dwyer } \\
\text { \& Boomsma, 2015; } \\
\text { O'Dwyer \& } \\
\text { Unerman, 2007) }\end{array}$ & $\begin{array}{l}\text { Balanced, more } \\
\text { participatory prospective } \\
\text { mechanisms needed } \\
\text { (Dawson, 1998; } \\
\text { O'Dwyer \& Boomsma, } \\
\text { 2015; O'Dwyer \& } \\
\text { Unerman, 2007) }\end{array}$ \\
\hline $\begin{array}{l}\text { Infrastructure } \\
\text { CSOs }\end{array}$ & Unknown & $\begin{array}{l}\text { Strategic prioritised } \\
\text { over functional } \\
\text { (Macmillan, 2008) }\end{array}$ & $\begin{array}{l}\text { Retrospective necessary } \\
\text { but more prospective } \\
\text { needed (Cupitt \& } \\
\text { Mihailidou, 2009) }\end{array}$ \\
\hline $\begin{array}{l}\text { Membership } \\
\text { CSOs }\end{array}$ & $\begin{array}{l}\text { Downwards } \\
\text { (Ebrahim, 2003b; } \\
\text { Loft et al, 2006) }\end{array}$ & $\begin{array}{l}\text { Functional (Awio et } \\
\text { al, 2011) }\end{array}$ & $\begin{array}{l}\text { Retrospective including } \\
\text { participatory mechanisms } \\
\text { (Koppell, 2005) }\end{array}$ \\
\hline Philanthropists & $\begin{array}{l}\text { Expected upwards } \\
\text { but more downwards } \\
\text { needed (Botetzagias } \\
\text { \& Koutiva, 2014; } \\
\text { Coyte et al, 2013) }\end{array}$ & $\begin{array}{l}\text { Strategic prioritised } \\
\text { over functional } \\
\text { (Kreander et al, } \\
\text { 2009; Mckinney \& } \\
\text { Kahn, 2004) }\end{array}$ & $\begin{array}{l}\text { Retrospective, but more } \\
\text { participatory mechanisms } \\
\text { needed (Leat, 2004) }\end{array}$ \\
\hline $\begin{array}{l}\text { Service } \\
\text { Providers }\end{array}$ & $\begin{array}{l}\text { Balanced, more } \\
\text { downwards needed } \\
\text { to offset upwards } \\
\text { dominance (Bennett } \\
\text { \& Savani, 2011; } \\
\text { Tenbensel et al, } \\
\text { 2007) }\end{array}$ & $\begin{array}{l}\text { Mainly functional } \\
\text { (Cribb, 2006; } \\
\text { Ebrahim, 2003a) }\end{array}$ & $\begin{array}{l}\text { Retrospective including } \\
\text { participatory mechanisms } \\
\text { (Cutt et al, 1996) }\end{array}$ \\
\hline
\end{tabular}

\section{METHODS}

These case studies infer different CSO types have different accountability styles (see Table 4). Our categorisation, based on funding and activity, investigates: "how does diversity affect accountability discharge across the CSO sector?" utilising a survey to obtain a broad array of responses. Practitioner and academic research in the CSO sector commonly uses surveys to 
observe trends, attitudes and opinions (see: Connolly et al, 2013; Hyndman \& McDonnell, 2009; Irvine et al, 2009; Ward \& McKillop, 2010). Nevertheless, good design and crosschecks are important (Stopher, 2012). Hence, we pilot tested the survey with eight potential respondents, and actioned their feedback. To increase the response rate and reduce nonresponse bias, prior to releasing the survey release, we contacted the chosen sample, introduced the survey and checked contact details (Stopher, 2012). While surveys obtain a broad range of views, the possibilities of detailed insights are limited (Connolly et al, 2013).

Our sample included 1,096 relevant CSOs from two New Zealand data sets. We obtained a mailing list of 167 advocacy organisations from research; including Trade Unions, national and local advocacy groups (see Grey \& Sedgwick, 2013). Further, we obtained two samplesets totalling 929 other CSOs from the New Zealand Charities Register randomly selected from the population of charities with annual operating expenditure of less than NZ\$2,000,000 (Cordery et al, 2015). ${ }^{\text {viii }}$ Similar to other jurisdictions, small charities comprise $96 \%$ of the total number of New Zealand's registered charities (Cordery et al, 2015). Our survey asked 'to whom' CSOs believed they were accountable (upward and downward), 'for what' they were accountable (functional and strategic) and the key mechanisms used (retrospective and prospective). ${ }^{\mathrm{ix}}$ Table 5 shows a total of 653 CSOs opened the survey and 433 provided analysable responses $(39.5 \%)$.

Table 5: Total Analysable Responses from Survey

\begin{tabular}{|l|r|r|r|r|}
\hline CSO Categorisation & \# Surveyed & \# Opened & Analysable responses & Percent Response \\
\hline Advocacy & 167 & 104 & 68 & $40.72 \%$ \\
Classic Charities & 431 & 255 & 166 & $38.52 \%$ \\
Infrastructure & 42 & 24 & 18 & $42.86 \%$ \\
Membership & 74 & 48 & 33 & $44.59 \%$ \\
Trust/ Grantor & 128 & 63 & 41 & $32.03 \%$ \\
Service Providers & 254 & 159 & 107 & $42.13 \%$ \\
\hline Total & 1096 & 653 & 433 & $39.51 \%$ \\
\hline
\end{tabular}

Respondents were asked about their CSO's stakeholder reporting and engagement. This, phrase was used instead of 'accountability' due to accountability's connotation of obligation. Survey options included: (i) 12 possible stakeholder groups to whom they report and engage, whether upwards and downwards (see Table 1); (ii) 16 possible reasons for reporting and engaging with those stakeholders, whether functional and strategic (see Table 2); and (iii) 12 possible reporting/engagement mechanisms, whether retrospective and prospective (see Table 3). ${ }^{x}$ 
For each comparison of interest (upward/downward, functional/strategic and retrospective/prospective), we calculated summary scores by counting how many options the respondent chose, as well as the percentage of total options chosen. Analysis of Variance (ANOVA) compares the means of these summary scores between the different CSO types and we also report the summary F statistic, its degrees of freedom (df) and p-value. Tukey's Post Hoc tests clarify which pairwise differences between groups are statistically significant at the 0.05 level and chi-squared statistics compare the proportions within each CSO type responding "yes" or "no" to specific survey items. Data analysis is conducted using IBM SPSS Version 21 (IBM Corp. Released 2012. IBM SPSS Statistics for Windows, Version 21.0)

\section{FINDINGS}

\section{Stakeholders 'to whom' accountable}

We asked respondents to identify 'to whom' they reported or engaged, in the prior twelve months - a period which covers a typical accountability cycle (including AGMs) but does not task the respondent's memory. To evaluate the literature review findings (see Table 4), each CSO could select up to six upwards stakeholders and six downwards stakeholders. This section presents findings on statistical differences in:

(i) the total number of different stakeholders reported to or engaged with, by CSO type; and

(ii) CSOs' emphasis on upwards stakeholders (the percentage of the total number of stakeholders they report to or engage with). For example, an advocacy CSO reports to 6 stakeholders of which 3 or $50 \%$ are upwards (see Table 6).

The mean total number of stakeholders reported to or engaged with differs by CSO type (p $<.00005)$. CSOs identified between 3 and 5.3 (25\% - 44\% of 12) stakeholder groups. Tukey's multiple comparison test shows Advocacy, Classic Charities and Service Providers report to the most stakeholders, and Infrastructure and Philanthropists report to the least (p $<.05)$. Statistically no difference exists in emphasis between CSO types. On average, 50$57 \%$ of the stakeholders reported to, were upwards. We call this balanced. 
Table 6: CSOs' Accountability to Upwards and Downwards Stakeholders

\begin{tabular}{|c|c|c|c|c|c|c|}
\hline $\begin{array}{l}\text { Score } \\
\text { categorisation }\end{array}$ & $\mathrm{CSO}$ & $\mathrm{N}$ & Mean $\%$ & $\begin{array}{c}\text { Std. } \\
\text { Deviation }\end{array}$ & $\mathrm{F}$ & Sig. \\
\hline \multirow{7}{*}{$\begin{array}{l}\text { (i) } \\
\text { Total number } \\
\text { of Upwards + } \\
\text { Downwards } \\
\text { stakeholders } \\
(\mathrm{n} / 12)\end{array}$} & Advocacy & 68 & 5.2941 & 2.17214 & \multirow{7}{*}{$\begin{array}{r}6.870 \\
=5,427 \\
\end{array}$} & \multirow[b]{7}{*}{$\mathrm{p}<0.0005$} \\
\hline & Classic Charities & 166 & 4.6747 & 2.25957 & & \\
\hline & Infrastructure & 18 & 3.7222 & 2.19104 & & \\
\hline & Membership & 33 & 3.9697 & 1.59069 & & \\
\hline & Philanthropists & 41 & 3.0488 & 1.81592 & & \\
\hline & Service Providers & 107 & 4.7103 & 2.21491 & & \\
\hline & Total & 433 & 4.5335 & 2.22140 & & \\
\hline \multirow{7}{*}{$\begin{array}{l}\text { (ii) } \\
\text { Emphasis on } \\
\text { Upwards } \\
\text { stakeholders } \\
\text { (as a \% of } \\
\text { total } \\
\text { stakeholders) }\end{array}$} & Advocacy & 68 & 49.9741 & 20.9317 & \multirow{7}{*}{$\begin{array}{r}1.264 \\
\mathrm{df}=5,427\end{array}$} & \multirow[b]{7}{*}{$\mathrm{p}=0.279$} \\
\hline & Classic Charities & 166 & 57.1476 & 21.0991 & & \\
\hline & Infrastructure & 18 & 55.3704 & 29.3534 & & \\
\hline & Membership & 33 & 55.1010 & 19.3871 & & \\
\hline & Philanthropists & 41 & 53.4306 & 29.3285 & & \\
\hline & Service Providers & 107 & 57.3620 & 20.4303 & & \\
\hline & Total & 433 & 4.5335 & 2.22140 & & \\
\hline
\end{tabular}

Shading shows where CSO types are statistically significantly different (Tukey test, $p<.05$ ) from other CSO categorisation and are in the higher scoring group (many stakeholder groups).

Advocacy CSOs report or engage with the most stakeholder groups $(5.29 / 12)(\mathrm{p}<.0005)$ being in the higher scoring group. They differ statistically, being likely to report or engage with government $\left(\chi^{2}(5)=19.280, p=.002\right)$, those they advocate for $\left(\chi^{2}(5)=42.552\right.$, $\mathrm{p}<.0005)$, staff $\left(\chi^{2}(5)=17.579, \mathrm{p}=.004\right)$, and those who use their infrastructure $\left(\chi^{2}(5)=\right.$ $20.789, \mathrm{p}=.001)$. They are statistically unlikely to select grantmakers $\left(\chi^{2}(5)=30.401\right.$, $\mathrm{p}<.0005)$.

Classic Charities are in the higher scoring group of CSOs reporting to many stakeholder groups in total, as are Service Providers (both $\mathrm{p}<.0005$ ). Dissimilarly, Infrastructure CSOs report to few stakeholder groups in total $(\mathrm{p}<.0005)$.

Membership CSOs are not statistically different overall, but are unlikely not to currently report or engage with members $\left(\chi^{2}(5)=18.369, p=.003\right)$ (that is, they are likely to), and are unlikely to report to those who use their infrastructure $\left(\chi^{2}(5)=20.789, p=.001\right)$.

Philanthropists list the least number of stakeholders to whom they report or engage with in total $(3.04 / 6)(\mathrm{p}<.0005)$. Philanthropists are likely not to report or engage with donors $\left(\chi^{2}(5)\right.$ 
$=17.943, \mathrm{p}=.003)$, funders $\left(\chi^{2}(5)=14.012, \mathrm{p}=.016\right)$, grantmakers $\left(\chi^{2}(5)=30.401, \mathrm{p}<.0005\right)$, $\operatorname{staff}\left(\chi^{2}(5)=17.579, p=.004\right)$, and members $\left(\chi^{2}(5)=18.369, p=.003\right)$.

\section{'For what' of accountability}

We asked respondents to identify 'for what' (why) they reported or engaged in the prior twelve months. To evaluate the literature review findings (see Table 4), each CSO could select up to eight strategic and eight functional reasons. This section presents statistical differences in:

(i) the total number of reasons for reporting or engaging with stakeholders, by CSO type; and

(ii) CSOs' emphasis on functional reasons (the percentage of the total number of reasons to report or engage). For example, an Advocacy CSO gave 12 reasons to report to stakeholders of which 6 or $50 \%$ were functional (see Table 7).

Table 7: CSOs' Focus on Functional and Strategic Accountability Reasons

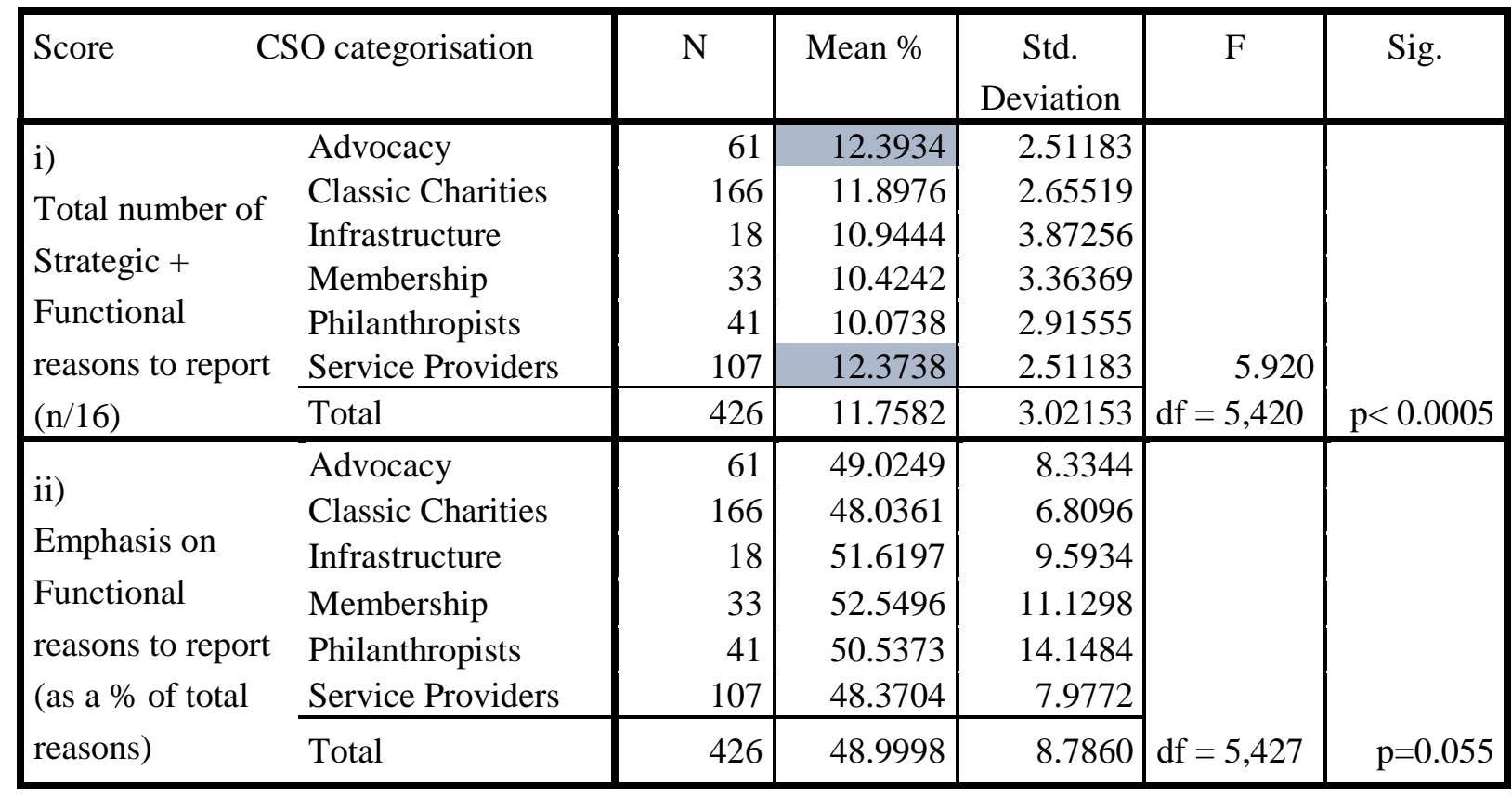

Shading shows where CSO types are statistically significantly different (Tukey test, $\mathrm{p}<.05$ ) from other CSO categorisation and are in the higher scoring group (many reasons).

The mean total number of reasons for reporting to or engaging with stakeholders differs by CSO type $(\mathrm{p}<.00005)$. CSOs identifid between 10-12.4 (62.5\%-78\% of 16) reasons.

Tukey's multiple comparison test shows Advocacy and Service Providers providing the most reasons to report, and Philanthropists and Membership CSOs the least ( $\mathrm{p}<.05)$. Statistically, 
no difference exists in emphasis between CSO types $(\mathrm{p}=.055)$. On average $48-52.5 \%$ were functional. We call this balanced.

Nevertheless, Advocacy CSOs are unusual compared to the other CSOs, choosing the most reasons to be accountable in total $(12.39 / 16)(\mathrm{p}<.0005)$. They are statistically unlikely to state they "never" report in order to collaborate with other CSOs $\left(\chi^{2}(5)=25.362, p<.0005\right)$ (that is a strategic accountability reason).

Classic Charities are significantly unlikely to state they "never" report to continue to obtain funds and donations for operations $\left(\chi^{2}(5)=69.523, p<.0005\right)$ (a functional accountability reason). Further, Infrastructure CSOs are significantly likely to "never" discharge accountability: for continuing to obtain funds and donations for operations $\left(\chi^{2}(5)=69.523\right.$, $\mathrm{p}<.0005)$, or showing how they deliver quality programmes and services to members and beneficiaries $\left(\chi^{2}(5)=34.227, p<.0005\right)$.

Membership CSOs are significantly unlikely to: show how they deliver on their mission/strategic plan $\left(\chi^{2}(5)=13.8934, p=.016\right)$, be honest about their long term impact on others $\left(\chi^{2}(5)=15.770, p=.008\right)$ and be accountable for planning for the future of the CSO sector and for supporting it $\left(\chi^{2}(5)=17.036, \mathrm{p}=0.004\right)$ (strategic reasons).

Philanthropist CSOs report the least total reasons to be accountable $(10.07 / 16)(\mathrm{p}<.0005)$. They are significantly unlikely to choose functional reasons: to obtain funds and donations for their operations $\left(\chi^{2}(5)=69.523, \mathrm{p}<.0005\right)$, to deliver quality programmes and services to members and beneficiaries $\left(\chi^{2}(5)=34.227, p<.0005\right)$, to satisfy lenders/investors $\left(\chi^{2}(5)=\right.$ $12.129, \mathrm{p}=.033$ ) and to be accountable for how they maintained their infrastructure for others to use $\left(\chi^{2}(5)=14.737, \mathrm{p}=.012\right)$. They are also unlikely to discharge strategic accountability not: being responsive to the community's on-going needs $\left(\chi^{2}(5)=26.930, p<.0005\right)$, collaborating with other CSOs $\left(\chi^{2}(5)=23.362, p<.0005\right)$, or being honest about their long term impact on others $\left(\chi^{2}(5)=15.770, \mathrm{p}=.008\right)$.

Service providers are similar to Advocacy CSOs, scoring in the higher group of CSOs for total reasons to be accountable ( $\mathrm{p}<.0005)$, but are not statistically different in respect of specific responses. 


\section{Key Accountability Mechanisms Used}

We asked respondents to identify 'how' they reported to or engaged with stakeholders in the prior twelve months. To evaluate the literature review findings (see Table 4), each CSO could select up to six prospective and six retrospective mechanisms. This section presents statistical differences in:

(i) the total number of mechanisms they used to report to or engage with stakeholders, by CSO type; and

(ii) the emphasis on retrospective reasons (the percentage of total number of mechanisms they use to report or engage). For example, an Advocacy CSO gave 6 reasons to report to stakeholders of which 4 or $66 \%$ were retrospective (see Table 8).

Table 8: CSOs' Use of Retrospective and Prospective Accountability Mechanisms

\begin{tabular}{|ll|r|r|r|r|r|}
\hline Score & CSO categorisation & N & Mean \% & Std. Deviation & F & Sig. \\
\cline { 1 - 4 } i) & Advocacy & 68 & 6.3529 & 2.49635 & & \\
Total number & Classic Charities & 166 & 5.8855 & 2.35208 & & \\
of & Infrastructure & 18 & 5.1667 & 2.83362 & & \\
Retrospective & Membership & 33 & 5.7576 & 1.82055 & & \\
+ Prospective & Philanthropists & 41 & 3.8293 & 2.31195 & & \\
mechanisms & Service Providers & 107 & 6.2804 & 2.54319 & 7.358 & \\
(n/12) & Total & 433 & 5.8222 & 2.49319 & df $=5,427$ & p $<0.0005$ \\
\cline { 1 - 4 } ii) & Advocacy & 68 & 58.1075 & 15.0308 & & \\
Emphasis on & Classic Charities & 166 & 66.2028 & 17.0773 & & \\
Retrospective & Infrastructure & 18 & 70.4762 & 20.5785 & & \\
mechanisms & Membership & 33 & 62.9233 & 16.3721 & & \\
(as a & Philanthropists & 41 & 77.9960 & 23.9115 & & \\
\% of total & Service Providers & 107 & 64.5792 & 16.1170 & 7.135 & \\
\cline { 2 - 5 } mechanisms) & Total & 433 & 65.5491 & 18.0096 & df $=5,427$ & p $<0.0005$ \\
\hline
\end{tabular}

Shading shows where CSO types are statistically significantly different (Tukey test, $\mathrm{p}<.05$ ) from other CSO categorisation and are in the higher scoring group (many mechanisms/ greater retrospective emphasis).

The mean total number of mechanisms differs by CSO type $(\mathrm{p}<.00005)$. CSOs identified between 3.8-6.35 (31\%-53\% of 12) mechanisms. Tukey's multiple comparison test shows Infrastructure and Philanthropists CSOs utilise more than $66 \%$ retrospective mechanisms, with Advocacy CSOs are 58\%. Since none are 'balanced' (close to 50\%), with retrospective 
mechanisms are emphasised unilaterally, we describe those with $66 \%$ or more as prioritising retrospective.

Advocacy CSOs use, on average, the least retrospective mechanisms $(58 \%)(\mathrm{p}<.0005)$ and the most mechanisms in total $(6.35 / 12)(\mathrm{p}<.0005)$. They are significantly likely to consult prospectively with members $\left(\chi^{2}(5)=17.365, \mathrm{p}=0.004\right)$.

Classic Charities utilise some prospective mechanisms (34\% compared to 66\% retrospective) ( $p<.0005)$, being in the higher scoring group, using many prospective and retrospective mechanisms in total $(\mathrm{p}<.0005)$. They are significantly unlikely to disagree that they "had not": reported to funders $\left(\chi^{2}(5)=32.129, p<.0005\right)$, or had an audit $\left(\chi^{2}(5)=17.008, p=.004\right)$ (that is, they had utilised these retrospective mechanisms).

Infrastructure CSOs are in the higher scoring group for a retrospective focus and use few mechanisms. They are significantly likely, on average, not to have reported to funders $\left(\chi^{2}(5)\right.$ $=32.129, \mathrm{p}<.0005)$ or have elections $\left(\chi^{2}(5)=44.262, \mathrm{p}<.0005\right)$.

Membership CSOs utilise some prospective mechanisms (37\% compared to 63\% retrospective $)(\mathrm{p}<.0005)$ and use many mechanisms in total $(\mathrm{p}<.0005)$. They are significantly unlikely on average, to seek retrospective accreditation $\left(\chi^{2}(5)=16.605, p=.005\right)$.

Philanthropists had the highest focus on retrospective mechanisms $(78 \%)(\mathrm{p}<.0005)$ and used the least mechanisms in total $(3.82 / 12)(\mathrm{p}<.0005)$. They are significantly unlikely to undertake retrospective: reporting to funders $\left(\chi^{2}(5)=32.129, \mathrm{p}<.0005\right)$, holding an AGM $\left(\chi^{2}\right.$ $(5)=20.957, \mathrm{p}=.001)$, having an audit $\left(\chi^{2}(5)=17.008, \mathrm{p}=0.004\right)$, publishing a budget $\left(\chi^{2}(5)\right.$ $=18.938, \mathrm{p}=0.002)$ or gaining accreditation $\left(\chi^{2}(5)=16.605, \mathrm{p}=0.005\right)$. They are significantly unlikely to undertake prospective: elections $\left(\chi^{2}(5)=44.262, p<.0005\right)$, or open meetings $\left(\chi^{2}(5)=13.705, p=0.008\right)$.

Service Providers utilise some prospective mechanisms (35\% compared to 65\% retrospective $)(\mathrm{p}<.0005)$ and use many mechanisms in total $(\mathrm{p}<.0005)$. They are unlikely to state that they "had not" had an $\operatorname{AGM}\left(\chi^{2}(5)=20.957, p=.001\right)$ (retrospective), or to have elections $\left(\chi^{2}(5)=44.262\right.$, p<.0005) (prospective). That is, they hold both. 
Table 9: Focus on Accountability by CSO Sector (Table 4 compared to empirical results)

\begin{tabular}{|c|c|c|c|c|c|c|}
\hline \multirow{2}{*}{ Type of CSO } & \multicolumn{2}{|c|}{ To whom (upwards/downwards) } & \multicolumn{2}{|c|}{ For what (functional/strategic) } & \multicolumn{2}{|c|}{ How (retrospective/prospective) } \\
\hline & Literature argues: & This survey finds: & Literature argues: & This survey finds: & Literature argues: & This survey finds: \\
\hline Advocacy CSOs & \multirow{2}{*}{$\begin{array}{l}\text { Balanced, more } \\
\text { downwards } \\
\text { stakeholders } \\
\text { needed to offset } \\
\text { upwards } \\
\text { dominance }\end{array}$} & $\begin{array}{l}\text { Balanced, many (most) } \\
\text { stakeholder groups } \\
\text { (especially government, } \\
\text { advocates, staff) }\end{array}$ & $\begin{array}{l}\text { Strategic } \\
\text { prioritised over } \\
\text { functional }\end{array}$ & $\begin{array}{l}\text { Balanced, many } \\
\text { reasons (most) }\end{array}$ & $\begin{array}{l}\text { Balanced, more } \\
\text { prospective } \\
\text { mechanisms needed }\end{array}$ & $\begin{array}{l}\text { Greater than } 1 / 3^{\text {rd }} \\
\text { prospective, many } \\
\text { (most) mechanisms } \\
\text { (especially member } \\
\text { consultation) }\end{array}$ \\
\hline Classic Charities & & $\begin{array}{l}\text { Balanced, many } \\
\text { stakeholder groups }\end{array}$ & $\begin{array}{l}\text { Balanced between } \\
\text { strategic and } \\
\text { functional }\end{array}$ & $\begin{array}{l}\text { Balanced - } \\
\text { focused on } \\
\text { fundraising }\end{array}$ & $\begin{array}{l}\text { Balanced, more } \\
\text { participatory } \\
\text { mechanisms needed }\end{array}$ & $\begin{array}{l}\text { Greater than } 1 / 3^{\text {rd }} \\
\text { prospective, many } \\
\text { mechanisms (especially } \\
\text { funder reporting/audits) }\end{array}$ \\
\hline $\begin{array}{l}\text { Infrastructure } \\
\text { CSOs }\end{array}$ & Unknown & $\begin{array}{l}\text { Balanced, few } \\
\text { stakeholder groups }\end{array}$ & $\begin{array}{l}\text { Strategic } \\
\text { prioritised over } \\
\text { functional }\end{array}$ & Balanced & $\begin{array}{l}\text { Retrospective } \\
\text { necessary, but more } \\
\text { prospective needed }\end{array}$ & $\begin{array}{l}\text { Fewer than } 1 / 3^{\text {rd }} \\
\text { prospective, elections } \\
\text { unlikely }\end{array}$ \\
\hline $\begin{array}{l}\text { Membership } \\
\text { CSOs }\end{array}$ & Downwards focus & $\begin{array}{l}\text { Balanced, few } \\
\text { downwards stakeholder } \\
\text { groups (except } \\
\text { members) }\end{array}$ & Functional & $\begin{array}{l}\text { Balanced, few } \\
\text { reasons }\end{array}$ & $\begin{array}{l}\text { Retrospective } \\
\text { including } \\
\text { participatory } \\
\text { mechanisms }\end{array}$ & $\begin{array}{l}\text { Greater than } 1 / 3^{\text {rd }} \\
\text { prospective, many } \\
\text { mechanisms }\end{array}$ \\
\hline Philanthropists & $\begin{array}{l}\text { Expected upwards } \\
\text { but argues for more } \\
\text { downwards }\end{array}$ & $\begin{array}{l}\text { Balanced, but few } \\
\text { (least) stakeholder } \\
\text { groups }\end{array}$ & $\begin{array}{l}\text { Strategic } \\
\text { prioritised over } \\
\text { functional }\end{array}$ & $\begin{array}{l}\text { Balanced, few } \\
\text { reasons (least) }\end{array}$ & $\begin{array}{l}\text { Retrospective } \\
\text { necessary, but more } \\
\text { prospective needed }\end{array}$ & $\begin{array}{l}\text { Fewer than } 1 / 3^{\text {rd }} \\
\text { prospective, few } \\
\text { mechanisms }\end{array}$ \\
\hline Service Providers & $\begin{array}{l}\text { Balanced, more } \\
\text { downwards needed } \\
\text { to offset upwards } \\
\text { dominance }\end{array}$ & $\begin{array}{l}\text { Balanced, many } \\
\text { stakeholder groups }\end{array}$ & Mainly functional & $\begin{array}{l}\text { Balanced, many } \\
\text { reasons }\end{array}$ & $\begin{array}{l}\text { Retrospective } \\
\text { including } \\
\text { participatory } \\
\text { mechanisms }\end{array}$ & $\begin{array}{l}\text { Greater than } 1 / 3^{\text {rd }} \\
\text { prospective, many } \\
\text { mechanisms (especially } \\
\text { AGMs/elections) }\end{array}$ \\
\hline
\end{tabular}




\section{DISCUSSION}

Table 9 restates Table 4 from the literature review, comparing and contrasting prior literature and the survey results. Advocacy CSOs are the 'busiest' in terms of 'to whom', 'for what', and 'how' they discharge accountability. They report or engage with the most stakeholder groups. As their revenue and expenditure is the highest of the CSO types, perhaps their size is advantageous. Advocacy CSOs are the most likely to engage with government, people they advocate for, and infrastructure users, although their accountability is balanced across different stakeholder groups and accountability reasons. More than one-third of their mechanisms are prospective, particularly member consultation. Advocacy CSOs exhibit openness called for in prior literature (Knutsen \& Brower, 2010; Unerman \& O’Dwyer, 2006a, 2006b), but resources may constrain this (Dawson, 1998). Case study literature evidences these struggles (for example, O’Dwyer and Unerman, 2008).

Despite Classic Charities receiving the majority of their funds from donors (upwards stakeholders, see Hyndman \& McDonnell, 2009; Najam, 1996), they are not statistically more likely to report and engage with upwards stakeholders. They are very 'busy' with many stakeholder groups, reasons and mechanisms. Classic Charities' mechanisms and main reasons to discharge accountability are angled toward funds' collection, which could potentially jeopardise mission fulfilment (for example, Irvine et al, 2009; O’Dwyer \& Boomsma, 2015). While O'Dwyer and Unerman (2008) suggest that donor-funded CSOs discharge strategic over functional accountability, these Classic Charities are balanced. Further, more than one-third of their mechanisms are prospective rather than retrospective. Connolly et al (2013) seek relevant reporting, which prospective reporting may enhance. However, Classic Charities' high number of accountability mechanisms may make them too busy to change.

Infrastructure CSOs, seldom highlighted in the academic literature, vitally support the CSO sector, mitigating its insufficiencies and enhancing democracy through meeting space provision (Brown \& Kalegaonkar, 2002; Cupitt \& Mihailidou, 2009; Macmillan, 2008). Nevertheless, the Infrastructure CSOs surveyed list few stakeholder groups. This limits users' ability to demand accountability, and Infrastructure CSOs necessary responsiveness to communities' ongoing needs (see Irvine et al, 2009). They are otherwise 'balanced' in terms of upwards/downwards and functional/strategic. They use less than one-third prospective 
accountability mechanisms, being unlikely to hold elections. Further research is needed to deepen our understanding of these CSOs.

Many stakeholder groups also challenge Membership CSOs (Koppell, 2005); nevertheless they balance upwards and downwards stakeholders. Membership CSOs also balance functional/strategic reasons to be accountable, despite Ebrahim (2003b) arguing otherwise. Also contrary to prior literature, Membership CSOs utilise more than one-third prospective mechanisms, are member focused and use many mechanisms.

Philanthropist CSOs are balanced, but list few stakeholder groups, being dependent on selffunding and investments (Coyte et al, 2013; Irvin, 2005; Leat, 2004). They seek to influence social change as well as make grants (Tomei, 2013), suggesting a need for strategic grantmaking. Yet, Philanthropist CSOs note few strategic or functional accountability reasons. They appear not to critically analyse their impact on funded CSOs (Irvine et al, 2009; McKinney and Kahn, 2004), or discharge accountability to end-beneficiaries. They are unlikely to use consultative (prospective) or retrospective mechanisms, utilising very few accountability mechanisms overall. Further research is needed into their management of their indirect link to end-beneficiaries, and how other CSOs hold them accountable.

Service Providers are expected to predominantly account upwards (Brown \& Moore, 2001; Tenbensel et al, 2007), but, similarly to intentions reported in Cribb (2006), this research finds they are balanced. Utilising many mechanisms, their high use of AGMs/elections evidence Service Providers seek democratic input, as Christensen and Ebrahim (2006) also find. Although Ebrahim (2003a) suggests Service Providers will focus on functional accountability, this survey shows balance with many strategic reasons, potentially as they need to collaborate to survive (Brown \& Moore, 2001; O’Dwyer \& Boomsma, 2015). More than one-third of their mechanisms are prospective, rather than retrospective.

Researchers contend CSOs must be accountable downwards and upwards (Najam, 1996; Roberts, 1991), deliver accountability for strategic and functional reasons (Ebrahim, 2003a; Edwards \& Hulme, 1996; Najam, 1996), and use prospective and retrospective mechanisms (Cutt et al, 1996). We show practice varies considerably. For accountability 'to whom', the Membership CSOs and Philanthropists are more 'balanced' towards stakeholders than previously theorised (see Table 9). Although mean observations for the total number of upwards CSO stakeholder groups is higher (2.51/6 compared to 2.02/6 for downwards), the percentage of upwards/downwards stakeholders is approximately 50\% (see Table 6). 
Similarly surprising is the balance between strategic and functional accountability reasons. The literature suggests functional accountability prioritisation, but we found a positive balance with an average 6.06/8 strategic and 5.69/8 functional, making the percentage of strategic/functional accountability reasons approximately 50\% (see Table 7). Although literature argues Advocacy CSOs, Infrastructure CSOs and Philanthropists would be strategic, they discharge more balanced accountability. Further, Service Providers and Membership CSOs, expected to prioritise functional, discharge more balanced accountability.

Many CSO types use more than one-third of prospective mechanisms (Advocacy CSOs, Classic Charities, Membership CSOs and Service Providers). The literature has not previously discussed an 'ideal' percentage, but these are more strongly prospective (although still functionally focused) than Infrastructure CSOs and Philanthropists. Table 8 shows that overall, retrospective mechanisms prevail.

\section{CONCLUSION}

Gray et al (2006) recommend a principles-based approach to accountability, being concerned about balancing CSO size, their stakeholder groups and stakeholders' demands. We respond to their call by testing a schema tailored to dominant stakeholders and activity, specifically analysing smaller CSOs. One principle developed is that accountability varies across different CSO types. Prior literature expects CSOs to discharge accountability homogeneously, but we find CSOs in different categorisations exhibiting different accountability 'profiles' as to stakeholders they are accountable to; the reasons to discharge accountability; and the focus and number of prospective and retrospective mechanisms.

Following increased public expectations for accountability and regulation, this pan-sector survey finds CSOs being pushed to 'balanced' accountability discharge, making the second principle balance, and not only satisfying dominant stakeholders for functional reasons. Calls for dominant stakeholders to require CSOs to discharge more downwards accountability (Bennett \& Savani, 2011; Christensen \& Ebrahim, 2006; Hwang \& Powell, 2009; Hyndman \& McDonnell, 2009) may assist. Yet, we question, what is the 'balance' or level of emphasis of retrospective/prospective reporting? A third principle is therefore seeking multiple-use mechanisms, potentially requiring CSOs to bargain with dominant stakeholders (see Goddard \& Assad, 2006; O’Dwyer \& Boomsma, 2015). Further research is required into the feasibility of multiple-use mechanisms, especially as this pan-sector study evidences frenetic 
accountability activity, suggesting reductions would be welcome. We echo Gray et al's (2006) concern, that smaller CSOs are swamped by demands.

Although other researchers (including Teegen et al, 2004; Unerman \& O’Dwyer, 2006a) define CSOs by the activities they undertake, we provide a more nuanced understanding of accountability. A CSO's activity/mission should be understood in combination with its stakeholders. We strengthen Hansmann's (1986) and Anheier and Themudo's (2002) arguments that CSOs management/stakeholder control is important, further extending their dichotomous theorising into a six-CSO categorisation.

Observing CSO ‘average accountability', Philanthropist and Infrastructure CSOs are outliers. They are less open, with few prospective mechanisms and few mechanisms overall. We confirm prior concerns about these private institutions' accountability deficit and paucity of democratic input (Irvin, 2005; Leat, 2004; Tomei, 2013). Advocacy CSOs are the opposite, being 'very busy' discharging accountability, making them likely to experience 'multiple accountabilities disorder' (Koppell, 2005).

This research has limitations, as not all CSOs fit neatly into single categories, nevertheless this charge could be levied at any categorisation. The significant survey results support using Cordery et al's (2015) categorisation to enable a nuanced understanding of accountability. By studying 'to whom' and 'for what' of accountability across a diverse sector, we show pansector balance, warning about activity levels. The research also distinguishes between prospective/retrospective mechanisms, questioning where an adequate balance might lie.

Our testing and extension of Cordery et al's (2015) categorisation highlights similarities and differences for CSOs to better understand themselves. We particularly emphasise uniqueness in Advocacy CSOs, Philanthropists and Infrastructure CSOs which exhibit extreme observations. Further research is needed into Infrastructure CSOs' and Philanthropists' accountability discharge. We know little about these significant CSO financiers and resource providers who impact the future of civil society. 


\section{REFERENCES}

Agyemang, G., M. Awumbila, J. Unerman and B. O’Dwyer (2009), NGO Accountability and Aid Delivery, Available at: http://www.accaglobal.com/content/dam/acca/global/PDFtechnical/sustainability-reporting/rr-110-001.pdf.

Anheier, H.K. and N. Themudo (2002), 'Organizational forms of global civil society: implications of going global', in M. Glasius, M. Kaldor, \& H. Anheier (eds). Global Civil Society, Oxford University Press, Oxford.

Awio, G., D. Northcott, and S. Lawrence (2011), 'Social capital and accountability in grassroots NGOs: The case of the Ugandan community-led HIV/AIDS initiative', Accounting, Auditing \& Accountability Journal, Vol. 24, No 1, pp.63-92.

Bennett, R. and S. Savani (2011), 'Surviving Mission Drift', Nonprofit Management and Leadership, Vol. 22, No 2, pp.217-231.

Botetzagias, I. and E. Koutiva (2014), 'Financial Giving of Foundations and Businesses to Environmental NGOs: The Role of Grantee's Legitimacy', Voluntas: International Journal of Voluntary and Nonprofit Organisations, Vol. 25, No 2, pp.281-306.

Brown, L.D. and A. Kalegaonkar (2002), 'Support Organizations and the Evolution of the NGO Sector', Nonprofit and Voluntary Sector Quarterly, Vol. 31, No 2, pp.231-258. and M.H. Moore (2001), 'Accountability, Strategy, and International Nongovernmental Organizations', Nonprofit and Voluntary Sector Quarterly, Vol. 30, No 3, pp.569-587.

Christensen, R.A. and A. Ebrahim (2006), 'How does accountability affect mission? The case of a nonprofit serving immigrants and refugees', Nonprofit Management and Leadership, Vol. 17, No 2, pp.195-209.

Connolly, C., A. Dhanani and N. Hyndman (2013), The Accountability Mechanisms and Needs of External Charity Stakeholders.

Cordery, C.J. (2005), The Charity Annual General Meeting: is it an accountability mechanism? Unpublished thesis, Victoria University of Wellington, Wellington. . and R.F. Baskerville (2011), 'Charity Transgressions, Trust and Accountability', Voluntas: International Journal of Voluntary and Nonprofit Organizations, Vol. 22, No 2, pp.197-213.

(2011), 'Not reporting a profit - constructing a non-profit organisation', Financial Accountability and Management, Vol. 27, No 4, pp.363-384.

Cordery, C.J. and K. Patel (2011), Financial Reporting Stocktake: An Assessment of Accountability through Charities' Filings on New Zealand's Charities Register, Victoria University of Wellington, Wellington. 
D. Sim and T. van Zijl (2015), 'Differentiated Regulation: the case of charities', Accounting and Finance, forthcoming.

Coyte, R., J. Rooney and B. Phua (2013), 'The Impossibility of Philanthropic Funding Decisions : The Australian Non-Government Funder Experience', Financial Accountability and Management, Vol. 29, No. 4, pp.397-418.

Cribb, J. (2006), 'Paying the Piper? Voluntary Organisations, Accountability and Government Contracting', Third Sector Review, Vol. 12, No 1, pp.25-37.

Cupitt, S. and A. Mihailidou (2009), Demonstrating the Difference, London. Available at: http://www.ces-vol.org.uk/NR/rdonlyres/51B638F2-7E96-4A89-8B898F53E233CF5B/0/demonstratingthedifference392400.pdf.

Cutt, J., D. Bragg, K. Balfour, V. Murray and W Tassie (1996), 'The Information Demands of Public and Private Funders', Nonprofit Management \& Leadership, Vol. 7, No 1, pp.45-67.

Dawson, E. (1998), 'The relevance of social audit for Oxfam GB', Journal of Business Ethics, Vol. 17, No 13, pp.1457-1469.

Delfin, F.G. and S.-Y. Tang (2006), 'Philanthropic Strategies in Place-Based, Collaborative Land Conservation: The Packard Foundation's Conserving California Landscape Initiative', Nonprofit and Voluntary Sector Quarterly, Vol. 35, No 3, pp.405-429.

Desai, A.M. and R.J. Yetman (2005), Constraining managers without owners: governance of the not-for-profit enterprise, National Bureau of Economic Research, Cambridge, MA.

DiMaggio, P.J. and H.K. Anheier (1990), 'The Sociology of Nonprofit Organizations', Annual Review of Sociology, Vol. 16, No 1990, pp.137-159.

Dixon, R., J. Ritchie and J. Siwale (2006), 'Microfinance: accountability from the grassroots', Accounting, Auditing \& Accountability Journal, Vol. 19, No 3, pp.405-427.

Ebrahim, A. (2003a), 'Accountability in practice: mechanisms for NGOs', World Development, Vol. 31, No 5, pp.813-829.

(2003b), 'Making sense of accountability: conceptual perspectives for northern and southern nonprofits', Nonprofit Management and Leadership, Vol. 14, No 2, pp.191-212.

Edwards, M. (2000), NGO Rights and responsibilities - a New Deal for Global Governance, The Foregin Policy Centre, London, UK.

and D. Hulme (1996), Non-governmental Organisations - Performance and Accountability: Beyond the Magic Bullet, Earthscan Publications, London.

Freeman, R.E. (1994), Strategic Management: A Stakeholder Approach, Pitman Publishing, Boston. 
Goddard, A. and M.J. Assad (2006), 'Accounting and navigating legitimacy in Tanzanian NGOs', Accounting, Auditing \& Accountability Journal, Vol. 19, No 3, pp.377-404.

Gray, R., J. Bebbington and D. Collison (2006), 'NGOs, civil society and accountability: making the people accountable to capital', Accounting, Auditing \& Accountability Journal, Vol. 19, No 3, pp.319-348.

Grey, S. and C. Sedgwick (2013), 'The Contract State and Constrained Democracy the community and voluntary sector under threat', Policy Quarterly, Vol. 9, No 3, pp.3-10.

Hansmann, H.B. (1986), 'The role of nonprofit enterprise', in S. Rose-Ackerman (ed.), The Economics of Nonprofit Institutions: Studies in Structure and Policy. Oxford University Press, New York.

Hwang, H. and W.W. Powell (2009), 'The Rationalization of Charity: The Influences of Professionalism in the Nonprofit Sector', Administrative Science Quarterly, Vol. 54, No 2, pp.268-298.

Hyndman, N. and P. McDonnell (2009), 'Governance and Charities: an exploration of key themes and the development of a research agenda', Financial Accountability \& Management, Vol. 25, No 1, pp.5-31.

Irvin, R.A. (2005), 'State regulation of nonprofit organizations: Accountability regardless of outcome.',Nonprofit and Voluntary Sector Quarterly, Vol. 34, No 2, pp.161-178.

Irvine, H., K. Lazarevski and S. Dolnicar (2009), 'Strings Attached: New Public Management, Competitive Grant Funding and Social Capital', Financial Accountability and Management, Vol. 25, No. 2, pp.225-252.

Jayasinghe, K. and D. Wickramasinghe (2011), 'Power over empowerment: Encountering development accounting in a Sri Lankan fishing village', Critical Perspectives on Accounting, Vol. 22, No 4, pp.396-414.

Jung, T. and J. Harrow (2014), 'New development: Philanthropy in networked governancetreading with care', Public Money \& Management, Vol. 35, No 1, pp.47-52.

Kluvers, R. (2001), 'Budgeting in catholic parishes: an exploratory study.',Financial Accountability \& Management, Vol. 17, No 1, pp.41-58.

Knutsen, W.L. and R.S. Brower (2010), 'Managing Expressive and Instrumental Accountabilities in Nonprofit and Voluntary Organizations: A Qualitative Investigation', Nonprofit and Voluntary Sector Quarterly, Vol. 39, No 4, pp.588-610.

Koppell, J.G.S. (2005), 'Pathologies of accountability: ICANN and the challenge of "Multiple Accountabilities Disorder" Public Administration Review, Vol. 65, No 1, pp.94-108.

Kreander, N., V. Beattie and K. McPhail (2009), 'Putting our money where their mouth is: Alignment of charitable aims with charity investments - Tensions in policy and practice', The British Accounting Review, Vol. 41, No 3, pp.154-168. 
Laughlin, R. (1990), 'A model of financial accountability and the Church of England', Financial Accountability \& Management, Vol. 6, No 2, pp.93-114.

Leat, D. (2004), 'What do Australian foundations do - who knows and who cares?', Australian Journal of Public Administration, Vol. 63 (June), pp.96-105.

Lehman, G. (2007), 'The accountability of NGOs in civil society and its public spheres', Critical Perspectives on Accounting, Vol. 18, No 6, pp.645-669.

Loft, A., C. Humphrey and S. Turley (2006), 'In pursuit of global regulation: Changing governance and accountability structures at the International Federation of Accountants (IFAC)', Accounting, Auditing \& Accountability Journal, Vol. 19, No 3, pp.428-451.

Macmillan, R. (2008), A Shape of Things to Come Reviewing County Durham 's Voluntary and Community Sector Infrastructure, Sheffield.

Mckinney, R. and H. Kahn (2004), 'Lottery Funding and Changing Organizational Identity in the UK Voluntary Sector', Voluntas: International Journal of Voluntary and Nonprofit Organizations, Vol. 15, No 1, pp.1-19.

Mitchell, R.K., R.B. Agle, R.B. and D.J. Wood (1997), 'Toward a theory of stakeholder identification and salience: defining the principle of who and what really counts', Academy of Management Review, Vol. 4, pp.853-886.

Mourey, D., P. Eynaud and C.J. Cordery (2013), 'The Impact of Governmental Policy on the Effective Operation of CSOs: A French Case Study', Nonprofit Policy Forum, Vol. 5, No 1, pp.169-193.

Najam, A. (1996), 'NGO accountability: A conceptual framework', Development Policy Review, Vol. 14, pp.339-353.

O’Dwyer, B. and R. Boomsma (2015), 'The co-construction of NGO accountability: Aligning imposed and felt accountability in NGO-funder accountability relationships', Accounting, Auditing \& Accountability Journal, Vol. 28, No 1, pp.36-68.

and J. Unerman (2007), 'From functional to social accountability: transforming the accountability relationships between funders and non-governmental development organisations', Accounting, Auditing \& Accountability Journal, Vol. 20, No 3, pp.446471.

(2008), 'The paradox of greater NGO accountability: A case study of Amnesty Ireland', Accounting, Organizations and Society, Vol. 33, No 7/8, pp.801824.

Osborne, S., T. Bovaird, S. Martin, M. Tricker and P. Waterston (1995), 'Performance Management and Accountability in Complex Public Programmes', Financial Accountability \& Management, Vol. 11, No 1, pp.19-37. 
Ospina, S., W. Diaz and J.F. O'Sullivan (2002), 'Negotiating accountability: managerial lessons from identity-based nonprofit organizations', Nonprofit and Voluntary Sector Quarterly, Vol. 31, No 1, pp.5-31.

Parker, L.D. (2003), 'Financial management strategy in a community welfare organisations: a boardroom perspective', Financial Accountability \& Management, Vol. 19, No 4, pp.341-374.

Roberts, J. (1991), 'The possibilities of accountability', Accounting, Organizations and Society, Vol. 16, No 4, pp.355-368.

Salamon, L.M., S.W. Sokolowski, M.A. Haddock and H.S. Tice (2012), The State of Global Civil Society and Volunteering: Latest findings from the implementation of the UN Nonprofit Handbook, Baltimore MD.

Salamon, L.M. and H.K. Anheier (1992a), 'In search of the non-profit sector II The problem of classification', Voluntas: International Journal of Voluntary and Nonprofit Organizations, Vol. 3, No 3, pp.267-309.

(1992b), 'In search of the non-profit sector. I: The question of definitions', Voluntas: International Journal of Voluntary and Nonprofit Organizations, 3(2), pp.125-151.

Statistics New Zealand (2007), Non-profit Institutions Satellite Account: 2004 Statistics New Zealand, ed., Wellington.

Stopher, P. (2012), Collecting, Managing and Assessing Data: using sample surveys, Cambridge University Press, New York, NY.

SustainAbility, Global Compact \& United Nations Environment Programme (2003), The 21st Century NGO: In the Market for Change, Available at:

http://www.sustainability.com/library/the-21st-century-ngo\#.UBIMMLTY_To.

Teegen, H., J.P. Doh and S. Vachani (2004), 'The importance of nongovernmental organizations (NGOs) in global governance and value creation: an international business research agenda', Journal of International Business Studies, Vol. 35, No 6, pp.463-483.

Tenbensel, T., N. Mays and J. Cumming, J (2007), Report No. 11: Public Sector Management and the New Zealand Public Health and Disability Act, Health Services Research Centre, Victoria University of Wellington, Wellington.

Tomei, A. (2013), 'Foundations: accountability and legitimacy', Voluntary Sector Review, Vol. 9, No 4, pp.403-413.

Unerman, J. and B. O'Dwyer (2006a), 'On James Bond and the importance of NGO accountability', Accounting, Auditing \& Accountability Journal, Vol. 19, No 3, pp.305318.

(2006b), 'Theorising accountability for NGO advocacy', Accounting, Auditing \& Accountability Journal, Vol. 19, No 3, pp.349-376. 
Vakil, A.C. (1997), 'Confronting the classification problem: toward a taxonomy of NGOs', World Development, Vol. 25, No 12, pp.2057-2070.

Valentinov, V. (2011), 'Accountability and the Public Interest in the Nonprofit Sector: a conceptual framework', Financial Accountability and Management, Vol. 27, No 1, pp.32-42.

Ward, A.M. and D. McKillop (2010), 'Profiling: a Strategy for Successful Volunteer Recruitment in Credit Unions', Financial Accountability \& Management, Vol. 26, No 4, pp.367-391.

Weisbrod, B.A. (1988), The Nonprofit Economy, Harvard University Press Cambridge, MA.

i These form a sector known variously as "third" or "nonprofit".

ii These are: culture, sports and recreation; education and research; health; social services; environment; development and housing; law, advocacy and politics; grant-making, fundraising and volunteerism promotion; international; religion; business and professional associations, unions; and 'not elsewhere classified'.

iii Urgent stakeholders call for immediate attention/action; are 'dangerous' when they possess power, 'dependent' when they possess legitimacy and 'definitive' when they possess legitimacy and power (Mitchell et al, 1997).

iv We use the term 'downwards' for both lateral and downwards stakeholders.

v Edwards \& Hulme, 1996 use the term "tactical" instead.

vi Macmillan (2008) includes service as well as structural providers as Infrastructure CSOs.

vii We focused on external mechanisms likely to be used by non-large CSOs and did not include formal social auditing and self-regulation (highlighted by Agyemang et al, 2009; Ebrahim, 2003a).

viii This is the equivalent of USD1,263,000, GBP817,000, or EUR1,115,000. Revenues of these entities ranged from NZ\$0-5,329,334, assets from NZ\$0-25,156,933 and liabilities from NZ\$0-13,584,493.

ix The survey instrument is available from the authors. Physical surveys were mailed to CSOs without email addresses, and otherwise provided electronically, using Qualtrics. Surveys were sent to the contact identified by the charities regulator, or the prior survey (for Advocacy CSOs).

$x$ The survey was undertaken in the last half of 2013 and the results of the survey were provided in summary form to respondents. 